\title{
Effects of growth hormone co-treatment on in vitro fertilization outcomes in women with expected normal ovarian response
}

\author{
Büyüme hormonu ko-tedavisinin normal ovaryan cevap \\ beklenen infertil kadinların IVF sonuçlarına etkisi
}

\author{
(D) Firat Tülek ${ }^{1}$, (1) Alper Kahraman² \\ ${ }^{1}$ Memorial Ataşehir Hospital, Clinic of Obstetrics and Gynecology, İstanbul, Turkey \\ ${ }^{2}$ University of Health Sciences Turkey, Haseki Training and Research Hospital, Clinic of Obstetrics and Gynecology, İstanbul, Turkey
}

\begin{abstract}
Objective: This study aimed to evaluate the effects of adjuvant growth hormone (GH) therapy on in vitro fertilization outcomes in women with infertility with expected normal ovarian response who underwent gonadotropin-releasing hormone (GnRH) antagonist protocol with dual triggering.

Materials and Methods: Records of women who underwent GnRH antagonist cycles with dual triggering in a single tertiary center between 2017 and 2020 were retrospectively analyzed. A total of 1054 women with expected normal ovarian response were evaluated, of which 131 were found to receive GH cotreatment (study group). Moreover, 950 women did not receive any adjuvant therapy (control group). Their cycle outcomes were compared.

Results: The number of retrieved oocytes, oocyte maturation rates, quality of embryos, miscarriage rates, and multiple pregnancy rates were comparable among women who underwent GnRH antagonist cycles with and without GH co-treatment. The number of obtained 2PN embryos (5.68 \pm 2.46 vs 5.06 \pm 2.5 ; $\mathrm{p}=0.003)$, fertilization rates $(0.84 \pm 0.16$ vs $0.76 \pm 0.18$; $\mathrm{p}<0.001)$, implantation rates $(0.34$ vs $0.25 ; \mathrm{p}=0.006)$, clinical pregnancy rates ( $50.4 \%$ vs $38 \%$; $\mathrm{p}=0.008)$, and live birth delivery rates $(41.8 \%$ vs $32.2 \% ; \mathrm{p}=0.007)$ were significantly higher in women who received $\mathrm{GH}$ co-treatment.

Conclusion: GH co-treatment significantly increased the clinical pregnancy rates and live birth delivery rates in women with infertility and expected normal ovarian response who underwent GnRH antagonist protocol with dual triggering for oocyte maturation, which was possibly due to the increasing endometrial receptivity or improving oocyte quality.
\end{abstract}

Keywords: Growth hormone, infertility, dual trigger, live birth, in vitro fertilization

Öz

Amaç: Adjuvan büyüme hormonu kullanımının GnRH antagonist sikluslarında dual trigger uygulanan normal ovaryan cevap beklenen infertil kadınlarda siklus sonuçları üzerine etkisini araştırmaktadır.

Gereç ve Yöntemler: Üçüncü basamak bir infertilite merkezinde 2017 ile 2020 yllları arasında dual trigger ile GnRH antagonist siklusu uygulanan kadınların verileri retrospektif olarak taranmıştır. Toplamda 1054 normal ovaryan cevap beklenen infertil kadın çalıșmaya dahil edilmiștir. Yüz otuz bir hasta adjuvan büyüme hormonu almış ve çalışma grubuna dahil edilmiştir. Dokuz yüz elli üç hasta kontrol grubu olarak belirlenmiş ve siklus sonuçları karşılaștırılmıștır.

Bulgular: Elde edilen oosit sayısı, oosit matürasyon oranları, embriyo kalitesi, düşük oranları, çoğul gebelik oranları açısından çalısma ve kontrol grupları arasında fark bulunmamıştır. Elde edilen 2PN embriyo sayısı (5,68 2,46 vs $5,06 \pm 2,5 ; \mathrm{p}=0,003)$, fertilizasyon oranları $(0,84 \pm 0,16$ vs $0,76 \pm 0,18 ; \mathrm{p}<0,001)$, implantasyon oranları $(0,34$ vs 0,$25 ; \mathrm{p}=0,006)$, klinik gebelik oranları $(\% 50,4$ vs $\% 38 ; \mathrm{p}=0,008)$ ve canlı doğum hızları (\%41,8 vs \%32,2; $\mathrm{p}=0,007)$ adjuvan büyüme hormonu verilen kadınlarda anlamlı olarak yüksek saptanmıştır.

Sonuç: Adjuvan büyüme hormonu tedavisi normal ovaryan cevap beklenen infertil kadınlarda klinik gebelik oranları ve canlı doğum oranlarını anlamlı sekilde artırmaktadır.

Anahtar Kelimeler: Büyüme hormonu, infertilite, dual trigger, canlı doğum, in vitro fertilizasyon

PRECIS: We retrospectively evaluated the effects of adjuvant GH administration on IVF outcomes of infertile women with normal ovarian response that were underwent GnRH antagonist cycles with dual trigger.

Address for Correspondence/Yazışma Adresi: Fırat Tülek MD, Memorial Ataşehir Hospital, Clinic of Obstetrics and Gynecology, İstanbul, Turkey Phone: +90 5306084874 E-mail: firattulek@yahoo.com ORCID ID: orcid.org/0000-0003-1668-8746

Received/Geliş Tarihi: 28.08.2021 Accepted/Kabul Tarihi: 17.10.2021

${ }^{\circledR}$ Copyright 2021 by Turkish Society of Obstetrics and Gynecology

Turkish Journal of Obstetrics and Gynecology published by Galenos Publishing House 


\section{Introduction}

Infertility is defined as the inability to achieve a pregnancy despite 1 year of unprotected intercourse. Worldwide, it affects approximately $10 \%$ of couples ${ }^{(1)}$. Infertility treatments are demanding in terms of financial, psychological, and physical aspects. Hence, infertility treatment, as well as subfertility, leads to frustration, brings anxiety, and creates distress in couples. The ultimate goal of assisted reproduction is pregnancy. Live birth rates in in vitro fertilization (IVF) cycles vary between $8 \%$ and 34\% worldwide ${ }^{(2)}$. Therefore, despite the substantial recent advances in IVF, most of the couples still could not reach this eventual goal in their first IVF attempts. Research about better techniques and convenient adjuvants to improve IVF outcomes are ubiquitously ongoing. Two of the under-studied therapies are the use of growth hormone (GH) as an adjuvant in IVF cycles and the triggering of oocyte maturation with a combination of gonadotropin-releasing hormone ( $\mathrm{GnRH}$ ) agonist and human chorionic gonadotropin (dual trigger).

$\mathrm{GH}$ is a peptide mainly secreted from somatotropic cells of anterior hypophysis that stimulate cellular growth and regeneration. Human granulosa cells, oocytes, and endometrial cells are known to express $\mathrm{GH}$ receptors ${ }^{(3)}$. GH was found to potentiate the effects of follicle-stimulating hormone (FSH) and to induce oocyte maturation ${ }^{(3)}$. Given these effects, the use of GH as an adjuvant in IVF cycles to increase success rates appears as a notable idea since the first study by Homburg et al. ${ }^{(4)}$ three decades ago. Although some data indicated that GH supplementation could improve reproductive outcomes and increase live birth delivery rates in poor responders, a few studies have evaluated the effects of GH supplementation on normoresponders and women with expected normal ovarian response with controversial results ${ }^{(5-18)}$. Therefore, literature data regarding this topic are still scarce.

In this study, we evaluated the effects of GH supplementation on IVF outcomes in women with normal prognosis who underwent GnRH antagonist cycle with dual triggering.

\section{Materials and Methods}

This study was conducted as retrospective analysis of patient records in a single tertiary center (Üsküdar University Faculty of Medicine) in Istanbul. Records of women who underwent GnRH antagonist cycles with dual triggering, either used adjuvant GH as physician's preference or no adjuvant at all between 2017 and 2020, were screened, and patients were contacted by phone when required.Ethical approval was obtained from the Ethical Committee of Üsküdar University Faculty of Medicine (approval no: 61351342/April 2021-81). The need for informed consent was waived by the ethical committee due to the retrospective design.

Patients with high $\left(>30 \mathrm{~kg} / \mathrm{m}^{2}\right)$ or low $\left(<18 \mathrm{~kg} / \mathrm{m}^{2}\right)$ body mass index; patients with endocrine disorders such as congenital adrenal hyperplasia, hyperprolactinemia, Addison disease, diabetes mellitus, Cushing syndrome, and thyroid dysfunction; patients with corrected or present uterine anomalies; and patients with severe male factor infertility were excluded from the study.

According to the POSEIDON classification, the low prognosis group of patients consisted of women with diminished ovarian reserves or women with suboptimal ovarian response in previous IVF attempts ${ }^{(19)}$. Patients considered as having a low prognosis according to the POSEIDON classification were also excluded from the analysis. Women with anti-Müllerian hormone levels $\geq 1.2 \mathrm{ng} / \mathrm{mL}$ and antral follicle count $\geq 5$ prior to the commencement of cycles who either have no other previous IVF attempts or at least 10 oocytes were retrieved in all previous IVF attempts were included in the study, and they were referred to as women with normal prognosis or women with expected normal ovarian response. Only outcomes of fresh embryo transfers were evaluated.

Controlled ovarian stimulation was initiated within the first 5 days of the menstrual cycle. Recombinant follicle-stimulating hormone (rFSH, Gonal-F, Merck Serono S.p.A, Italy), human menopausal gonadotropin (Merional, IBSA Institut Biochimique S.A, Menopur®, Ferring Pharmaceuticals, Switzerland), or a combination of recombinant luteinizing hormone and $\mathrm{rFSH}$ (Pergoveris, Merck Serono SA, Switzerland) were used for ovarian stimulation on practitioner's choice. Patients were monitored during stimulation for the follicular growth with serial transvaginal ultrasonography and serum hormone levels. Adjustments in gonadotropin doses were made based on each patient's follicular growth. Once the leading follicle was observed to reach a diameter of 12-14 mm, GnRH antagonist (Cetrotide $0.25 \mathrm{mg}$, Pierre Fabre Medicament Production, France) injections commenced to suppress premature LH peak and continued to the day of oocyte maturation triggering. Daily injections of $4 \mathrm{IU}$ (1.2 mg) of GH [Genotropin $36 \mathrm{IU}$ (12 MG) GoQuick, Pfizer Inc., Australia] were implemented starting from the day of cycle commencement to the day of oocyte triggering in women to whom adjuvant therapy was administered. The dual-triggering method was used to induce oocyte maturation with a GnRH agonist of $0.2 \mathrm{mg}$ triptorelin acetate (Gonapeptyl, Ferring Pharmaceuticals) and $250 \mathrm{mcg}$ recombinant human chorionic gonadotropin (Ovitrelle, Merck Serono) when at least one follicle reached a diameter of $18 \mathrm{~mm}$. Oocytes were retrieved under transvaginal ultrasound guidance 35-36 h after oocyte maturation triggering. Fertilization was conducted by intracytoplasmic sperm injection. Acquired embryos were graded according to Istanbul Consensus Workshop ${ }^{(20)}$. Day 3 or day 5 embryos were transferred by using an embryo transfer catheter under abdominal ultrasonography guidance depending on the condition. A maximum of two embryos were transferred at once following legal regulations. Luteal phase support was initiated in every patient with $200 \mathrm{mg}$ intravaginal progesterone (Lutinus, Ferring Pharmaceuticals) twice a day when endometrial thickness was observed to reach 7-8 $\mathrm{mm}$ and continued until $8^{\text {th }}-10^{\text {th }}$ gestational weeks. 
Patients with expected normal ovarian response who underwent GnRH antagonist cycle with dual triggering to whom adjuvant $\mathrm{GH}$ administered were assigned to the study group. The control group consisted of patients with normal prognosis who underwent GnRH antagonist cycle with dual triggering without adjuvant therapy within the selected period. The cycle outcomes of the study and control groups were compared. The primary outcome was live birth delivery rate. The secondary outcomes were the number of retrieved oocytes, number of metaphase 2 (M2) oocytes, oocyte maturation rates (M2 oocytes/retrieved oocytes), fertilization rates (2pronuclear embryos/M2 oocytes), implantation rates (gestational sacs observed/transferred embryos), number of obtained embryos, and grades of obtained embryos. Outcome parameters were described according to the International Glossary on Infertility and Fertility Care (2017) (21).

\section{Statistical Analysis}

Statistical analyses were performed using IBM SPSS v23 (IBM Corp, Armonk, NY, USA). Descriptive statistics were expressed as mean \pm standard deviations for normally distributed data. Categorical variables were expressed as numbers and percentages (\%). Significance of differences in means and medians among groups were assessed by Student's t-test and Mann-Whitney U test. Categorical variables were evaluated with Pearson's chi-squared test or Fisher's exact test. P-values $<0.05$ are considered significant.

\section{Results}

Following the exclusion of patients with confounding factors, a total of 131 women with expected normal ovarian response at the beginning of treatment were found to undergo GnRH antagonist cycles with dual triggering and received daily GH injections within the selected period. These women constituted the study group. GnRH antagonist cycles with dual triggering without adjuvant therapy were applied in 923 women with expected normal ovarian response, and these patients were assigned to the control group. The mean ages of the study and control groups were $35.17 \pm 3.82$ and $34.31 \pm 4.89$ years, respectively. The mean ages of groups were significantly comparable $(\mathrm{p}=0.077)$. The mean body mass index of the study and control groups were $25.15 \pm 2.71$ and $24.95 \pm 2.54$, respectively. No significant difference was found between the body mass index values of the groups $(\mathrm{p}=0.431)$. The causes of infertility within the study population were mild male factor, anovulation, tubal factor, endometriosis, and combined and unexplained factors. The prevalence of these etiologic factors was comparable between the groups $(\mathrm{p}=0.992)$. The distribution and comparison of the etiologic factors of infertility are presented in Table 1.

The total doses of gonadotropins required, stimulation length, and progesterone levels at the day of triggering were significantly higher in the control group than in the study group $(\mathrm{p}=0.013$,
Table 1. Distribution and comparison of infertility etiologies among the groups

\begin{tabular}{|c|c|c|c|}
\hline & $\begin{array}{l}\text { Study } \\
\text { group }\end{array}$ & $\begin{array}{l}\text { Control } \\
\text { group }\end{array}$ & p-value \\
\hline Number of patients & 131 & 923 & \\
\hline Mild male factor (n, \%) & $34(26 \%)$ & $261(28.3 \%)$ & \multirow{6}{*}{0.992} \\
\hline Anovulation (n, \%) & $31(23.7 \%)$ & $216(23.4 \%)$ & \\
\hline Tubal factor (n, \%) & $20(15.3 \%)$ & $128(13.9 \%)$ & \\
\hline Endometriosis (n, \%) & $12(9.2 \%)$ & $84(9.1 \%)$ & \\
\hline Combined (n, \%) & $9(6.9 \%)$ & $60(6.5 \%)$ & \\
\hline Unexplained (n, \%) & 25 (19.1\%) & $174(18.9 \%)$ & \\
\hline
\end{tabular}

$\mathrm{p}=0.036, \mathrm{p}=0.004$, respectively). Estradiol levels at the day of triggering, number of 2PN embryos obtained, fertilization rate, implantation rate, clinical pregnancy rate, and live birth delivery rates were significantly higher in cycles with $\mathrm{GH}$ injection $(\mathrm{p}<0.001, \mathrm{p}=0.003, \mathrm{p}<0.001, \mathrm{p}=0.006, \mathrm{p}=0.008, \mathrm{p}=0.007$, respectively). In women with $\mathrm{GH}$ co-treatment, the number of retrieved oocytes $(9.79 \pm 3.46$ vs $9.40 \pm 3.70 ; \mathrm{p}=0.128)$, number of M2 oocytes $(6.83 \pm 2.83$ vs $6.66 \pm 2.89 ; \mathrm{p}=0.426)$, oocyte maturation rates $(0.70 \pm 0.16$ vs $0.71 \pm 0.16 ; \mathrm{p}=0.275)$, biochemical pregnancy rates ( $13 \%$ vs $9.5 \%$; $\mathrm{p}=0.289$ ), miscarriage rates ( $9.9 \%$ vs $7.3 \%$; $\mathrm{p}=0.212$ ), multiple pregnancy rates $(2.3 \%$ vs $2.2 \% ; \mathrm{p}=0.299)$, endometrial thicknesses at the day of transfer $(10.16 \pm 1.65 \mathrm{~mm}$ vs $10.13 \pm 1.84 \mathrm{~mm} ; \mathrm{p}=0.6)$, and mean number of transferred embryos $(1.54 \pm 0.5$ vs $1.59 \pm 0.49$; $\mathrm{p}=0.326$ ) were all comparable with the control group. No significant differences were observed within groups in terms of the number of transferred grade 1 and 2 embryos, mean number of embryos transferred, and distribution of transfers due to the days of embryos. Cycle outcomes and comparison of these findings are summarized in Table 2.

A cost analysis was performed by using the momentary retail prices of medications in Turkey at the time of manuscript preparation. The mean cost of medications in the adjuvant $\mathrm{GH}$ group per cycle including $\mathrm{GH}$, gonadotropins, GnRH antagonists, and GnRH agonists was $377.7 \pm 131$ USD. In the control group, the mean estimated cost per cycle was $359.2 \pm 953$ USD. The mean cost of required medications were significantly comparable between the two groups $(\mathrm{p}=0.67)$.

\section{Discussion}

In this study, we evaluated the effects of GH co-treatment on IVF outcomes in women with expected normal ovarian response. Our results indicate significantly improved live birth delivery rates and clinical pregnancy rates in women with adjuvant $\mathrm{GH}$ administration.

A few studies have evaluated the outcomes of IVF cycles with GH supplementation in the normal population ${ }^{(14-17)}$. Younis et al. ${ }^{(17)}$ conducted a prospective randomized study involving 21 women with normal ovulation who underwent the GnRH 
Table 2. Comparison of cycle outcomes between the two groups

\begin{tabular}{|c|c|c|c|}
\hline & Study group & Control group & p-value \\
\hline Total dose of required gonadotropins & $2325.67 \pm 643.22$ & $2482.83 \pm 732.78$ & 0.013 \\
\hline Stimulation lenght (days) & $9.04 \pm 1.26$ & $9.38 \pm 1.51$ & 0.036 \\
\hline Estradiol levels on the day of triggering & $1833.92 \pm 674.77$ & $1586.37 \pm 742.91$ & $<0.001$ \\
\hline Progesterone levels on the day of triggering & $0.52 \pm 0.33$ & $0.59 \pm 0.31$ & 0.004 \\
\hline Number of 2PN embryos per cycle & $5.68 \pm 2.46$ & $5.06 \pm 2.5$ & 0.003 \\
\hline \multicolumn{4}{|l|}{ Number of embryos obtained } \\
\hline Grade 1 & $181(64.8 \%)$ & $1261(62.9 \%)$ & \multirow{3}{*}{0.586} \\
\hline Grade 2 & $90(31.1 \%)$ & $680(33.9 \%)$ & \\
\hline Grade 3 & $8(2.8 \%)$ & $62(3 \%)$ & \\
\hline \multicolumn{4}{|l|}{ Number of embryos transferred (\%) } \\
\hline Grade 1 & $162(80.2 \%)$ & $1190(81.2 \%)$ & \multirow{2}{*}{0.774} \\
\hline Grade 2 & $40(19.8 \%)$ & $275(18.8 \%)$ & \\
\hline Fertilization rate per cycle & $0.84 \pm 0.16$ & $0.76 \pm 0.18$ & $<0.001$ \\
\hline Implantation rate & $0.34(69 / 202)$ & $0.25(371 / 1465)$ & 0.006 \\
\hline Clinical pregnancy rate (no. of clicical pregnancies) & $50.4 \%(66)$ & $38 \%(351)$ & 0.008 \\
\hline Live birth delivery rate (no. of live births) & $41.8 \%(56)$ & $32.2 \%(304)$ & 0.007 \\
\hline
\end{tabular}

agonist protocol with daily injections of 12 IU of GH. They found higher number of pregnancies, implantation rates, and estradiol levels in the GH supplementation group; however, none of these parameters have reached significance. Moreover, they reported comparable gonadotropin requirements and estradiol levels in women with and without GH supplementation $^{(17)}$. Tapanainen et al. ${ }^{(16)}$ assessed 19 women with 24 IU of GH supplementation. Although the study was not designed to evaluate live birth delivery rates, they reported two pregnancies in the placebo group and only one pregnancy in the GH supplementation group. They also reported comparable gonadotropin requirements among the groups, and compared with other studies, they found lower estradiol levels in women treated with $\mathrm{GH}^{(16)}$. The results of these two aforementioned studies might be affected by the small sample sizes ${ }^{(16,17)}$. Du et al. ${ }^{(14)}$ retrospectively evaluated 556 women with infertility who underwent GnRH agonist cycles with 4.5 IU of $\mathrm{GH}$ supplementation. They found higher implantation rates and clinical pregnancy rates as well as higher embryo quality in women who received GH injections, but no differences were found in the required gonadotropin doses. Liu et al. ${ }^{(15)}$ assessed 781 normal responders who underwent IVF cycles with GH supplementation of doses varying between 2 IU and 4 IU. They found a higher clinical pregnancy rate in the overall GHadministered group, but without significance. As they stratified patients according to the administered GH doses, women who received 4 IU of $\mathrm{GH}$ had the highest clinical pregnancy rates and required the lowest gonadotropin stimulation ${ }^{(15)}$. In our study, we found increased clinical pregnancy rates and live birth delivery rates in women with normal prognosis who were treated with 4 IU of adjuvant GH.GH directly and indirectly participates in the regulation of reproductive functions ${ }^{(22)}$. No consensus was established regarding the optimal GH doses required in infertility treatments. A study reported increased pregnancy rates in poor responders with GH supplementation doses as low as $0.5 \mathrm{IU}^{(23)}$. An animal study indicated that $\mathrm{GH}$ might have bimodal inhibitory and stimulatory effects on various tissues ${ }^{(24)}$. For instance, Nakamura et al. ${ }^{(22)}$ demonstrated that in the presence of FSH, GH enhances early reactions in steroidogenic pathways by increasing local insulin-like growth factor-1 (IGF-1) levels but inhibits FSH-induced aromatase via an IGF-independent way. In higher concentrations, the IGF-independent inhibitory effects of GH might surpass the stimulatory effects. Furthermore, in an animal study, Singh and $\mathrm{Lal}^{(25)}$ mentioned the circadian effects of GH and showed increased ovarian steroidogenesis following GH injections in the morning but not in evening. The timing of GH injections within the day and doses might alter in vivo resultant effects of $\mathrm{GH}$ administration and contribute to different outcomes reported. In the present study, GH administrations were self-applied by the patient concomitant with gonadotropin injections. As a general adoption of practice, we recommend patients to execute injections between $6 \mathrm{pm}$ and $8 \mathrm{pm}$.

Previous studies have demonstrated that GH enhances progesterone production by augmenting the effects and production of IGF-1 ${ }^{(26)}$. Consistent with these findings, we found significantly higher progesterone levels in women with adjuvant GH administration. 
Endometrial cells are known to express GH receptors, and most studies have indicated an increase in endometrial receptivity after GH administration ${ }^{(27)}$. We found comparable endometrial thicknesses between the study and control groups. Although endometrial thickness is somehow associated with pregnancy rates in general, it is a poor predictor of clinical pregnancies alone, implying the participation of other factors in endometrial receptivity at the molecular level(28). Cui et al. ${ }^{(29)}$ demonstrated that $\mathrm{GH}$ increases endometrial receptivity by increasing the expression of integrin-beta 3 , a biomarker of endometrial receptivity, via IGF-dependent and IGGindependent pathways. To support these findings, we found significantly higher implantation rates in women who received $\mathrm{GH}$ supplementation despite the comparable number of transferred embryos and grades of transferred embryos between the study and control groups. Another possible explanation for the increased implantation rates in our study were the subtle improvements in embryo quality that morphological evaluations fail to demonstrate.

In a previous study, GH administration was shown to improve oocyte quality ${ }^{(30)}$. In the present study, the number of retrieved oocytes and M2 oocytes were not significantly different between the study and control groups. However, the number of 2PN embryos and fertilization rates were significantly higher in women with GH supplementation even if the grades of the obtained embryos were comparable between the groups. These findings might be a result of the increased oocyte quality in women who received GH injections.

Ovarian granulosa cells express GH receptors. GH is shown to potentiate the effects of FSH on granulosa cells and induce the proliferation of theca and granulosa cells ${ }^{(7)}$. In parallel with this information, we found significantly reduced gonadotropin requirements and stimulation lengths as well as significantly higher estradiol levels in the GH group in comparison with the control group.In the present study, we referred our study population as women with normal prognosis or women with expected normal ovarian response owing to our preference to the classification system suggested by the POSEIDON study group that utilized a more convenient approach to determine management strategies considering the prognosis of patients ${ }^{(19)}$. This choice of using the term "normal prognosis" or "expected normal ovarian response" was made to provide more functional data contributing to the clinical guidance in this group of patients.

\section{Study Limitations}

Despite the lack of comprehensive studies, some authors implicated that adult GH deficiency is fairly prevalent among women with infertility, based on their preliminary observations $^{(31)}$. Therefore, they suggested measurements of IGF-1 and IGH binding protein-3 (IGFBP-3) levels before the initiation of GH supplementation as women with GH deficiency might be the exact subgroup of patients who benefit from GH supplementation. As a study limitation, data of IGF-1 and IGFBP-3 levels were not available in patient records. Thus, future studies of adjuvant GH administration including IGF-1 and IGFBP-3 levels or other diagnostic tests to detect adult GH deficiency could help clarify the effects of GH supplementation and the subgroup of patients who could benefit most.

\section{Conclusion}

Our study demonstrate that daily injections of 4 IU of GH significantly increased the live birth delivery rates, clinical pregnancy rates, implantation rates, number of $2 \mathrm{PN}$ embryos obtained, and fertilization rates in women with expected normal ovarian response who underwent GnRH antagonist cycles with dual triggering, which was probably due to the increased endometrial receptivity and increased oocyte quality. Further studies designed with prognosis-based approaches could provide more data to make robust recommendations.

\section{Ethics}

Ethics Committee Approval: Ethical approval was obtained from the Ethical Committee of Üsküdar University Faculty of Medicine (approval no: 61351342/April 2021-81).

Informed Consent: The need for informed consent was waived by the ethical committee due to the retrospective design.

Peer-review: Externally and internally peer-reviewed.

\section{Authorship Contributions}

Concept: F.T., Design: F.T., Data Collection or Processing: F.T., Analysis or Interpretation: A.K., Literature Search: F.T., Writing: A.K.

Conflict of Interest: No conflict of interest was declared by the authors.

Financial Disclosure: The authors declared that this study received no financial support.

\section{References}

1. Deshpande PS, Gupta AS. Causes and prevalence of factors causing infertility in a public health facility. J Hum Reprod Sci 2019;12:28793.

2. Centers for Disease Control and Prevention. Assisted reproductive technology success rates: national summary and fertility clinic reports 2004. Atlanta, GA: Department of Health and Human Services, 2006.

3. Xu YM, Hao GM, Gao BL. Application of growth hormone in in vitro fertilization. Front Endocrinol (Lausanne) 2019;10:502.

4. Homburg R, Eshel A, Abdalla HI, Jacobs HS. Growth hormone facilitates ovulation induction by gonadotrophins. Clin Endocrinol 1988;1:113-7.

5. Choe SA, Kim MJ, Lee HJ, Kim J, Chang EM, Kim JW, et al. Increased proportion of mature oocytes with sustained-release growth hormone treatment in poor responders: a prospective randomized controlled study. Arch Gynecol Obstet 2018;297:7916 .

6. Ob'edkova K, Kogan I, Krikheli I, Dzhemlikhanova L, Muller V, Mekina I, et al. Growth hormone co-treatment in IVF/ICSI cycles in poor responders. Gynecol Endocrinol 2017;33(Supp 1):15-7. 
7. Yang $\mathrm{P}, \mathrm{Wu} \mathrm{R}$, Zhang $\mathrm{H}$. The effect of growth hormone supplementation in poor ovarian responders undergoing IVF or ICSI: a meta-analysis of randomized controlled trials. Reprod Biol Endocrinol 2020;18:76.

8. Safdarian L, Aghahosseini M, Alyasin A, Samaei Nouroozi A, Rashidi S, Shabani Nashtaei M, et al. Growth hormone (GH) Improvement of ovarian responses and pregnancy outcome in poor ovarian responders: a randomized study. Asian Pac J Cancer Prev 2019;20:2033-7.

9. Keane KN, Yovich JL, Hamidi A, Hinchliffe PM, Dhaliwal SS. Singlecentre retrospective analysis of growth hormone supplementation in IVF patients classified as poor-prognosis. BMJ Open 2017;7:e018107. doi:10.1136/bmjopen-2017-018107

10. Chu K, Pang W, Sun N, Zhang Q, Li W. Outcomes of poor responders following growth hormone co-treatment with IVF/ ICSI mild stimulation protocol: a retrospective cohort study. Arch Gynecol Obstet 2018;297:1317-21.

11. Cozzolino M, Cecchino GN, Troiano G, Romanelli C. Growth hormone cotreatment for poor responders undergoing in vitro fertilization cycles: a systematic review and meta-analysis. Fertil Steril 2020;114:97-109.

12. de Ziegler D, Streuli I, Meldrum DR, Chapron C. The value of growth hormone supplements in ART for poor ovarian responders. Fertil Steril 2011;96:1069-76.

13. Li J, Chen Q, Wang J, Huang G, Ye H. Does growth hormone supplementation improve oocyte competence and IVF outcomes in patients with poor embryonic development? A randomized controlled trial. BMC Pregnancy Childbirth 2020;20:310.

14. Du XF, Yang XH, Li J, Hao M, Guo YH. Growth hormone cotreatment within a GnRH agonist long protocol improves implantation and pregnancy rates in patients undergoing IVF-ET. Arch Gynecol Obstet 2016;294:877-83.

15. Liu X, Bai H, Xie J, Shi J. Growth hormone co-treatment on controlled ovarian stimulation in normal ovarian response women can improve embryo quality. Gynecol Endocrinol 2019;35:787-91.

16. Tapanainen J, Martikainen H, Voutilainen R, Orava M, Ruokonen A, Rönnberg L. Effect of growth hormone administration on human ovarian function and steroidogenic gene expression in granulosaluteal cells. Fertil Steril 1992;58:726-32.

17. Younis JS, Simon A, Koren R, Dorembus D, Schenker JG, Laufer $\mathrm{N}$. The effect of growth hormone supplementation on in vitro fertilization outcome: a prospective randomized placebo-controlled double-blind study. Fertil Steril 1992;58:575-80.

18. Li XL, Wang L, Lv F, Huang XM, Wang LP, Pan Y, et al. The influence of different growth hormone addition protocols to poor ovarian responders on clinical outcomes in controlled ovary stimulation cycles: A systematic review and meta-analysis. Medicine (Baltimore) 2017;96:e6443. doi:10.1097/MD.0000000000006443
19. Humaidan P, Alviggi C, Fischer R, Esteves SC. The novel POSEIDON stratification of 'Low prognosis patients in Assisted Reproductive Technology' and its proposed marker of successful outcome. F1000Res 2016;5:2911.

20. Alpha Scientists in Reproductive Medicine and ESHRE Special Interest Group of Embryology. The Istanbul consensus workshop on embryo assessment: proceedings of an expert meeting. Hum Reprod 2011;26:1270-83.

21. Zegers-Hochschild F, Adamson GD, Dyer S, Racowsky C, de Mouzon J, Sokol R, et al. The International Glossary on Infertility and Fertility Care, 2017. Fertil Steril 2017;108:393-406.

22. Nakamura E, Otsuka F, Inagaki K, Miyoshi T, Matsumoto Y, Ogura K, et al. Mutual regulation of growth hormone and bone morphogenetic protein system in steroidogenesis by rat granulosa cells. Endocrinology 2012;153:469-80.

23. Lattes K, Brassesco M, Gomez M, Checa MA. Low-dose growth hormone supplementation increases clinical pregnancy rate in poor responders undergoing in vitro fertilisation. Gynecol Endocrinol 2015;31:565-8.

24. Hull KL, Harvey S. Growth hormone and reproduction: a review of endocrine and autocrine/paracrine interactions. Int J Endocrinol 2014;2014:234014.

25. Singh AK, Lal B. Seasonal and circadian time-dependent dual action of $\mathrm{GH}$ on somatic growth and ovarian development in the Asian catfish, Clarias batrachus (Linn.): role of temperature. Gen Comp Endocrinol 2008;159:98-106.

26. Taketani T, Yamagata Y, Takasaki A, Matsuoka A, Tamura H, Sugino $\mathrm{N}$. Effects of growth hormone and insulin-like growth factor 1 on progesterone production in human luteinized granulosa cells. Fertil Steril 2008;90:744-8.

27. Altmäe S, Aghajanova L. Growth hormone and endometrial receptivity. Front Endocrinol (Lausanne) 2019;10:653.

28. Craciunas L, Gallos I, Chu J, Bourne T, Quenby S, Brosens JJ, et al. Conventional and modern markers of endometrial receptivity: a systematic review and meta-analysis. Hum Reprod Update 2019;25:202-23.

29. Cui N, Li AM, Luo ZY, Zhao ZM, Xu YM, Zhang J, et al. Effects of growth hormone on pregnancy rates of patients with thin endometrium. J Endocrinol Invest 2019;42:27-35.

30. Gong Y, Luo S, Fan P, Jin S, Zhu H, Deng T, et al. Growth hormone alleviates oxidative stress and improves oocyte quality in Chinese women with polycystic ovary syndrome: a randomized controlled trial. Sci Rep 2020;10:18769.

31. Yovich JL, Regan SLP, Zaidi S, Keane KN. The concept of growth hormone deficiency affecting clinical prognosis in IVF. Front Endocrinol (Lausanne) 2019;10:650. 